accordance with the speech vibrations, which result in a fluctuating current radiated to the receiver.

At the receiving end the oscillating current is changed into a uni-directional current, and made suitable for reception for hearing in an ordinary telephone receiver. It is an essential condition of reception that the receiving set be "tuned " to respond to the wave-length of the station it is desired to hear. Electrical waves emanating from a transmitter travel in all directions through space, and can be picked up by any number of receivers, provided these are tuned to receive the particular wave-length used.

Broadcasting stations comprise transmitting-room, studio, green-room, offices, listening-in, room, and workshop. Programmes are designed to operate throughout the whole evening, and all tastes and ages are catered for. It is usual for artistes to operate at the station, but by means of ordinary telephone transmission it is possible to transmit a political speech or entertainment from a central hall in a city to the broadcasting studio, and to radiate it from the station to listeners.

The pioneer work in broadcasting as a means of public entertainment and instruction was undertaken by the Westinghouse Co. of Pittsburgh, U.S.A., in December r920. The Metropolitan-Vickers Co. of Great Britain has close technical association with this company and has the advantage of this pioneer experience. There are now more than 500 broadcasting stations in the United States, and their growth without proper co-ordination has caused some confusion.

To avoid this confusion in Great Britain, the Government insisted that manufacturers of radio apparatus should co-operate in forming a Broadcasting Company to control broadcasting. Three stations of the eight contemplated are in operation, London, Manchester, and Birmingham, and it is intended that Newcastle shall have a station. The revenue of the Broadcasting Company for maintaining stations is provided by the manufacturers, but the Government assists by remitting a proportion of the licence fee.

Care should be taken in selecting a set suitable to the local conditions. A good crystal set costing about four or five pounds will receive satisfactorily over ten or fifteen miles. A two-valve set would pick up over fifty or one hundred miles, and in addition to this, a further two-valve amplifier could be arranged to increase the distance to 300 miles, or would permit the use of a loud speaker up to fifty miles. Sets sold by reputable manufacturers are very efficient and simple to operate.

The development of radio-telephony will have a very profound influence upon social life. It will overcome the isolation of the rural worker, the invalid, and those who are confined indoors, and it has unique potentialities for entertainment, instruction, and the development of public taste.

\section{Excavations at Borg en Nadur, Malta.}

$A^{\mathrm{T}}$ a meeting of the Royal Anthropological I Institute held on November 2r, Prof. F. G. Parsons, vice-president, in the chair, Miss Murray gave an account of some excavations carried out by her at Borg en Nadur, Malta, during the past summer. The excavation was purposely limited to a small area to the west of the so-called "dolmen " of Borg en Nadur in a terraced field which had been made over this site, as high as the cap-stone of the dolmen, and completely covering the remains of the ancient buildings. The principal building found was an apsidal structure of the type peculiar to Malta. From the small size of the stones and the primitive style of the building, Miss Murray is of the opinion that Borg en Nadur is considerably older than Mnaidra and Tarxien. The principal results of the excavation are (I) the discovery of types of pottery transitional between the neolithic and bronze age; (2) the finding of painted pottery showing Cretan influence, perhaps of the Middle Minoan era, thus connecting prehistoric Malta with another ancient civilisation.

In the discussion which followed the reading of the paper, Prof. J. L. Myres said the pottery of Malta presents a puzzling problem. Evidence is needed as to which of the large number of types are contemporary. The pottery from the "window tombs" of the lower levels of the ravines with flat alluvial bottoms, which form the characteristic watercourses of Malta, presents certain affinities with the "Sikel" pottery of Sicily. Miss Murray distinguished between "neolithic" and "bronze age" pottery; but, whereas she found the latter at ground level in the apsidal building, at Hal Tarxien the lower occupation layer, resting on ground level, contained no metal, and the bronze age interment had been found over a sterile layer of some thickness imposed upon the neolithic stratum and at a considerable height up the great stones of the temple. The painted pottery, for which a Cretan affinity had been suggested, is of the type found in Sicily and Southern Italy for which Prof. Peet had traced a Thessalian rather than an Ægean relationship. Prof. Myres also expressed his opinion that the Borg en Nadur building was of late and degenerate type rather than early and primitive. Mr. H. J. E. Peake said that Miss Murray's suggestion of a type of pottery transitional between the neolithic and bronze age types was new and needed substantiation. The restricted distribution of the "bronze age" type suggested that it might be an intrusion, of which Miss Murray's transitional type was an attempted copy.

\section{University and Educational Intelligence.}

Birmingham.-Dr. Dorothy Margaret Patrick has been appointed assistant lecturer in physiology, Grade III.

Mr. T. V. Barker, of the department of mineralogy at Oxford, has been invited to deliver a course of lectures, during the spring term, on chemical crystallography.

The annual meeting of the Court of Governors will be held on Thursday, February 8 .

The vice-chancellor (Sir Gilbert Barling, Bart.) is to represent the University at the celebration of the 8 ooth anniversary of the foundation of St. Bartholomew's Hospital in June next.

The new hall of residence for men students is to be known in future as Chancellor's Hall.

GLASGow.-The University has received a gift of 25,00ol. from Mr. Henry Mechan, of Mechans, Limited, engineers and contractors, Glasgow, for the foundation of a new chair of public health.

London.-At a meeting of the Senate on December $\Upsilon 3$, a resolution was adopted accepting a bequest of 3 oool. made by the late Sir William Meyer, fellow of University College and High Commissioner for India, to be applied at the discretion of the Senate "with special reference to the encouragement of proficiency in European History, and in the History and Geography of India." An offer from the council of the Society of Antiquaries to continue the Franks studentship in archæology, of the value of rool. per annum, for a further period of five years was accepted with thanks.

NO. 2773 , vOL. I IOT 
A grant of $\mathrm{r}_{5} l$. from the publication fund of the University has been made to the hon. editor for zoology of the Annals of Applied Biology in aid of the publication in that journal of the M.Sc. thesis entitled "The Life-History and Bionomics of the Turnip-Gall Weevil," by Mr. P. V. Isaac.

The degree of D.Lit. has been conferred on the Rev. G. H. Dix, an internal student, of King's College, for a thesis entitled " 'The Angel of Jahweh': A Study in the Origin and Development of a Religious FolkLegend, with special reference to the Messianic Expectation of the Hebrew Race."

THE general meeting of the Association of Women Science Teachers will be held at University College, Gower Street, on Saturday, January 6, r923. The programme includes an address by the retiring president and a lecture on relativity by Dr. Dorothy Wrinch. The hon. secretary of the association is Miss E. M. Ridley, ro Gresley Road, N.r9.

THE annual meeting of the Geographical Association will be held in Birkbeck College, London, E.C.4, on Thursday and Friday, January 4 and 5, I923, Sir John Russell will deliver his presidential address on the subject of "The Influence of Geographical Factors in the Agricultural Activities of a Population " on the opening day of the meeting. Among lectures to be given during the meeting are : "Types and Materials of Houses in England," Mr. H. Batsford; "The Place of Geography in the Education of the Adolescent," Dr. Olive Wheeler; "Geography and Business Life," Prof. W. S. Tower; "The Coming Industrialisation of China," Prof. P. M. Roxby.

THE second annual general meeting of the Association of Heads of Departments in Pure and Applied Science was held on Saturday, December 9, at the Woolwich Polytechnic. The members were welcomed by the chairman of the Governors, Mr. C. H. Grinling, who delivered an address upon the desirability of "association" in all branches of society, whether trade or professional, commercial or political. $\mathrm{He}$ emphasised the importance of a new association taking a long view of the range of their activities and of developing into a body of national, or better still, of international, rather than of merely parochial importance. The meeting decided later to extend the activities of the association by the admission of members from the provinces. Mr. C. E. Larard, of the Northampton Polytechnic, was elected as chairman, and Dr. W. A. Scoble and Mr. R. T. Smith, of Woolwich Polytechnic, as joint secretaries for the ensuing year.

THE report for I92I-22 by Dr. Cranage on the Cambridge University Local Lectures shows that the revival which took place in r9I9-2I has been maintained as regards the number of courses (92, of which I5 were on scientific subjects), but that the average attendance per lecture dropped from $\mathrm{x}_{42}$ in $\mathrm{I}_{920-2 \mathrm{I}}$ to 127 , and per class from 38 to 33 . The Summer Meeting (July 29 to Aug. I8) was attended by 544 students of whom 444 were women and 46 from foreign (chiefly Scandinavian) countries. The corresponding figures for I9I2 are 565,377 , and 226 . Considering that board and lodging were about twice and rail fares about three times as expensive as before the war, the popularity of the Summer Meeting is remarkable. Next July there will be held at Cambridge in connexion with the jubilee of the local lectures a conference on extra-mural teaching, the Chancellor presiding at the first meeting.

From the annual report for the year $192 \mathrm{I}-22$ issued by the Rhodes Trust, it appears that the number of
Rhodes scholars in residence during the year was 300 , of whom ${ }_{5} 6$ came from the British Empire and the remainder from the United States. Of the total, 66more than one-fifth-took natural science, a term which includes those studying medicine ; in addition, forestry and mathematics each had five scholars, agriculture three and anthropology one. During the year, 72 took up their scholarships for the first time. The current academic year commenced with 262 scholars in residence. The value of the Rhodes scholarship has been temporarily increased by an annual bonus of $50 l$., but applicants are warned that even thus, they must be prepared to find another 5ol. a year. Appointments to the I924 scholarships will be made during the year 1923 ; further information can be obtained from the offices of the Rhodes Trust, Seymour House, Waterloo Place, London, S.W.I.

THE Universities Bureau of the British Empire has published an abridged report of the proceedings of the annual conference of the universities of Great Britain and Ireland held last May. Four subjects were discussed: (I) the urgent need for enlarged opportunities for advanced study and research in the British universities ; (2) the increase of residential accommodation for students; (3) specialisation in certain subjects of study by certain universities; (4) the organisation of adult education as an integral part of the work of the universities. Mr. H. A. L. Fisher, then president of the Board of Education, attended the conference and took part in the discussion of subject (3), which he considered to be pre-eminently a subject for conference and co-operation among the universities, especially in regard to the financial requirements of new specialised departments, the application to the best advantage of existing trust funds in universities, and the migration of research students. The Report (pp. 32, price Is.) is obtainable from the Universities Bureau, 5o Russell Square, W.C.r.

THE eleventh annual conference of Educational Associations will be held at University College, Gower Street, W.C.I, on December 28-January 6, under the presidency of Sir Michael Sadler, Vice-Chancellor of the University of Leeds. The inaugural meeting will be held at Bedford College for Women, Regent's Park, on the afternoon of December 28, when Sir Michael Sadler will deliver his presidential address. There will be two joint conferences of all the societies during the meeting - one on the methods of carrying out in schools the recommendations of the reports on the Teaching of Classics, Modern Languages, English and Science, on December 30, and the other, "How can the Links in the Chain of Education be strengthened?" on January 5. The College of Preceptors will also hold a discussion, opened by Sir Michael Sadler, on the growth of bureaucracy in education. Among the papers which have been promised are: four to be delivered to the National League for Health, Maternity and Child Welfare-on physical development and its food requirements, by Dr. E. Pritchard, on physique and growth, by Dr. James Kerr, on child psychology and psychotherapy, by Dr. William Brown, and on health education, by Prof. H. Kenwood; three lectures on reform and tradition in education, by Mr. Frank Roscoe, to the College of Preceptors; a paper on the child and the cinema, by Dr. C. W. Kimmins, at the British Psychological Society (Education); another on the co-ordination of the teaching of mathematics with handicraft, by $\mathrm{Mr}$. A. Romney Green, at the Society for Experiment and Research in Education; one on hygiene as applied to physical training, by Prof. M. E. Delafield, at the Incorporated British Association for Physical Training; and one on relativity, by Dr. Dorothy Wrinch, at the Association of Women Science Teachers. 